\title{
Research on the influence of heat treatment temperature on bearing capacity of high steel grade pipeline during in-service welding
}

\author{
Yan Xu ${ }^{1}$, Yinglai Liu ${ }^{1}$, Xianghui Nie ${ }^{1}$, Zhenjun Feng ${ }^{1}$, Liang $\mathrm{Li}^{1}$, Fengping Yang $^{1}$, Jasmine ${ }^{2}$ \\ ${ }^{1}$ Tubular Goods Research Institute of CNPC, Xi'an, China \\ ${ }^{2}$ Companhia Brasileira de Metalurgia e Minerao, Brazil
}

\begin{abstract}
During the welding of in-service pipeline, natural gas is continuously transported in the pipeline, which maintains a high gas pressure. Therefore, the welding process is completed under strong cooling conditions, and welding delay crack is easy to occur. Preheating before welding and heat treatment after welding can effectively control the hardened microstructure, reduce the residual stress and ensure the welding quality. In this study, the influence of heating temperature on the bearing capacity of high steel grade pipe during in-service welding repair was studied. The high temperature tensile test was used to simulate the bearing capacity of the pipe under heating and high temperature environment. It is found that when the heating temperature is below $400^{\circ} \mathrm{C}$, the pipe strength remains at the original level. With the increase of heating temperature, when the test temperature is higher than $400^{\circ} \mathrm{C}$, the yield strength and tensile strength of the pipe decrease significantly. When the test temperature is $450^{\circ} \mathrm{C}$, the yield strength and tensile strength of the material decrease by $15.8 \%$ and $11.1 \%$, respectively, compared with the normal temperature, which are lower than the pipe standard requirements. Therefore, it is suggested that when the heat treatment temperature is higher than $400^{\circ} \mathrm{C}$ during in-service welding repair, it is necessary to consider reducing the pipeline pressure. At the same time, the box furnace heat treatment method was adopted to heat treat the pipe, and the tensile properties of the pipe after heat treatment were tested to analyze the bearing capacity of the pipe after heat treatment. It is found that when the heating temperature is higher than $700^{\circ} \mathrm{C}$, the tensile properties of high grade pipeline steel pipe decrease sharply. It is suggested that when the heat treatment temperature is higher than $700^{\circ} \mathrm{C}$, the risk assessment of the service safety of the heat treated pipeline should be carried out.
\end{abstract}

\section{Introduction}

In-service welding repair is one of the main repair methods in pipeline defects and leakage repair work. It can not only ensure the continuous pipeline transportation, but also reduce the degree of environmental damage, shorten the repair cycle and reduce the repair cost [1-2] . It has broad development prospects. At present, the inservice welding repair technology is faced with two technical difficulties, namely, burn-through and hydrogen-induced cracks [3-6] Among them, burnthrough mainly considers that the welding arc is instantaneously loaded on the pipe metal in the welding process, and the increases instantaneously. When the inner wall temperature of the pipe reaches $982{ }^{\circ} \mathrm{C}$, the local strength loss of the pipe metal will occur. Hydrogeninduced cracks mainly consider the continuous transmission of natural gas in the pipeline during the welding of the in-service pipeline, so the welding process is completed under strong cooling conditions, which is easy to produce welding delayed cracks. Preheating before welding and heat treatment after welding can effectively control the hardened structure, reduce the residual stress and ensure the welding quality. However, at present, the mainstream technology of pipeline steel production is to prepare high strength and toughness steel through low-carbon micro-alloying combined with thermo-mechanical control process. In practical application, when the heat treatment temperature is not controlled, the mechanical tensile properties of the pipe will change [7-10]. Therefore, it is necessary to study the influence of heat treatment temperature on the bearing capacity of high-grade pipeline during welding of inservice pipelines.

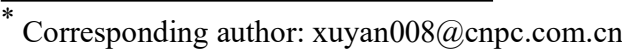




\section{Mechanical tensile properties of high grade steel pipes at high temperature}

\subsection{Test Materials and Methods}

The test material was taken from $\varphi 1016 \mathrm{~mm} \times 12.8 \mathrm{mmX} 80$ steel tube, and the chemical composition is shown in Table 1. The transverse rod-shaped specimen was taken at the pipe body for high temperature tensile test. The diameter of the gauge section of the specimen was $6.25 \mathrm{~mm}$, and the length of the gauge section was $25 \mathrm{~mm}$. The test equipment is CMT5105 material testing machine, and the test standard is ASTM E21-09.

Table 1. Chemical composition of test steel tubes (Wtx $100 \%)$

\begin{tabular}{ccccccccccccc}
\hline $\begin{array}{c}\text { com } \\
\text { posi } \\
\text { tion }\end{array}$ & $\mathrm{C}$ & $\begin{array}{l}\mathrm{S} \\
\mathrm{i}\end{array}$ & $\begin{array}{l}\mathrm{M} \\
\mathrm{n}\end{array}$ & $\mathrm{P}$ & $\mathrm{S}$ & $\begin{array}{c}\mathrm{C} \\
\mathrm{r}\end{array}$ & $\begin{array}{l}\mathrm{M} \\
\mathrm{o}\end{array}$ & $\mathrm{Ni}$ & $\begin{array}{c}\mathrm{N} \\
\mathrm{b}\end{array}$ & $\mathrm{V}$ & $\begin{array}{c}\mathrm{T} \\
\mathrm{i}\end{array}$ & $\begin{array}{c}\mathrm{C} \\
\mathrm{u}\end{array}$ \\
\hline & 0. & 0 & 1 & 0. & 0. & 0 & 0 & 0. & 0. & 0 & 0. & 0. \\
cont & 0 &. &. & 00 & 00 &. &. & 00 & 0 & 00 & 0 & 0 \\
ent & 4 & 1 & 8 & 72 & 23 & 3 & 2 & 84 & 8 & 63 & 1 & 1 \\
& 9 & 9 & 8 & & 4 & & 8 & & \\
\hline
\end{tabular}

\subsection{Test result}

High temperature tensile test results are shown in Figure 1. When the test temperature is below $400^{\circ} \mathrm{C}$, the strength index of the material fluctuates slightly. With the increase of test temperature, when the test temperature is higher than $400^{\circ} \mathrm{C}$, the yield strength and tensile strength of the material decrease significantly. When the test temperature is $450^{\circ} \mathrm{C}$, the yield strength of the material is $533 \mathrm{MPa}$, the tensile strength is $618 \mathrm{MPa}$, compared with the room temperature tensile properties decreased by $15.8 \%$ and $11.1 \%$, the value is lower than the standard requirements. Therefore, it is suggested that when the post-weld heat treatment temperature is higher than $400^{\circ} \mathrm{C}$, the depressurization treatment should be considered or the risk of in-service welding should be evaluated.

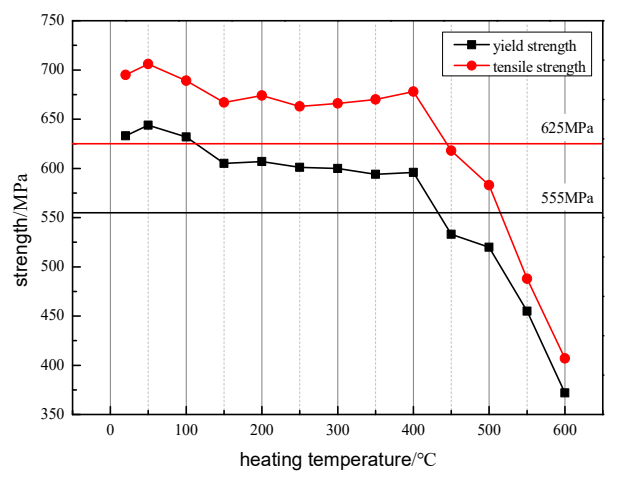

Figure 1. High temperature tensile test results

\section{Mechanical tensile properties of high grade steel pipe after heat treatment}

\subsection{Test Materials and Methods}

Four kinds of steel grade pipeline steel plates with different wall thicknesses were selected for heat treatment test. The chemical composition of the test material is shown in table 2 . The heat treatment process is as follows: the test plate is heated to $300^{\circ} \mathrm{C}, 500^{\circ} \mathrm{C}, 600^{\circ} \mathrm{C}, 700^{\circ} \mathrm{C}$, $900^{\circ} \mathrm{C}, 950^{\circ} \mathrm{C}, 1000^{\circ} \mathrm{C}$ and $1050^{\circ} \mathrm{C}$ respectively by box resistance furnace, and the furnace is cooled to room temperature after holding 55 minutes.

Table 2. Chemical composition of test steel tubes (Wtx $100 \%)$

\begin{tabular}{|c|c|c|c|c|c|c|c|c|c|c|c|c|}
\hline $\begin{array}{l}n \\
o \\
.\end{array}$ & $\begin{array}{c}\text { st } \\
\text { ee } \\
1 \\
\mathrm{gr} \\
\mathrm{ad} \\
\mathrm{e}\end{array}$ & $\begin{array}{c}\text { Thic } \\
\text { knes } \\
\mathrm{s} \\
\mathrm{mm}\end{array}$ & C & $\mathrm{Si}$ & $\begin{array}{c}\mathrm{M} \\
\mathrm{n}\end{array}$ & $\mathrm{P}$ & S & $\begin{array}{c}\mathrm{C} \\
\mathrm{r}\end{array}$ & $\begin{array}{c}\mathrm{N} \\
\mathrm{i}\end{array}$ & $\begin{array}{c}\mathrm{M} \\
\mathrm{o}\end{array}$ & $\begin{array}{l}\mathrm{N} \\
\mathrm{b}\end{array}$ & V \\
\hline $\begin{array}{l}1 \\
\#\end{array}$ & $\begin{array}{c}X \\
80\end{array}$ & 43 & $\begin{array}{c}0 . \\
04 \\
9\end{array}$ & $\begin{array}{l}0 . \\
2 \\
7\end{array}$ & $\begin{array}{l}1 . \\
5 \\
7\end{array}$ & $\begin{array}{c}0 . \\
00 \\
7\end{array}$ & $\begin{array}{c}0.0 \\
01 \\
3\end{array}$ & l & $\begin{array}{l}0 . \\
2 \\
1\end{array}$ & $\begin{array}{l}0 . \\
2 \\
3\end{array}$ & $\begin{array}{c}0 . \\
04 \\
5\end{array}$ & $\begin{array}{c}0 . \\
02 \\
5\end{array}$ \\
\hline $\begin{array}{l}2 \\
\#\end{array}$ & $\begin{array}{c}X \\
70\end{array}$ & 40 & $\begin{array}{c}0 . \\
06 \\
6\end{array}$ & $\begin{array}{l}0 . \\
2 \\
2\end{array}$ & $\begin{array}{l}1 . \\
5\end{array}$ & $\begin{array}{c}0 . \\
01 \\
3\end{array}$ & $\begin{array}{c}0.0 \\
01 \\
2\end{array}$ & / & $\begin{array}{l}0 . \\
2 \\
2\end{array}$ & $\begin{array}{l}0 . \\
2\end{array}$ & $\begin{array}{c}0 . \\
03 \\
7\end{array}$ & $\begin{array}{c}0 . \\
02\end{array}$ \\
\hline $\begin{array}{l}3 \\
\#\end{array}$ & $\begin{array}{c}X \\
60\end{array}$ & 36 & $\begin{array}{c}0 . \\
06 \\
3\end{array}$ & $\begin{array}{l}0 . \\
1 \\
6\end{array}$ & $\begin{array}{l}1 . \\
2 \\
9\end{array}$ & $\begin{array}{c}0 . \\
01 \\
1\end{array}$ & $\begin{array}{c}0.0 \\
02 \\
5\end{array}$ & $\begin{array}{c}0 . \\
1 \\
8\end{array}$ & $\begin{array}{l}0 . \\
2\end{array}$ & $\begin{array}{l}0 . \\
1 \\
9\end{array}$ & $\begin{array}{c}0 . \\
04 \\
1\end{array}$ & I \\
\hline $\begin{array}{l}4 \\
\#\end{array}$ & $\begin{array}{l}X \\
60\end{array}$ & 45 & $\begin{array}{c}0 . \\
1\end{array}$ & $\begin{array}{l}0 . \\
2 \\
7\end{array}$ & $\begin{array}{l}1 . \\
2 \\
2\end{array}$ & $\begin{array}{c}0 . \\
01\end{array}$ & $\begin{array}{c}0.0 \\
03 \\
5\end{array}$ & $\begin{array}{l}0 . \\
3 \\
9\end{array}$ & $\begin{array}{l}0 . \\
0 \\
1\end{array}$ & $\begin{array}{c}0 . \\
1 \\
5\end{array}$ & $\begin{array}{c}0 . \\
02 \\
4\end{array}$ & $\begin{array}{l}0 . \\
04\end{array}$ \\
\hline
\end{tabular}

The rod-like tensile samples were taken at the center of the wall thickness of the raw material and the heat-treated test block, respectively. The diameter of the gauge section was $12.7 \mathrm{~mm}$ and the length of the gauge section was $50 \mathrm{~mm}$. The tensile test was carried out on the UH-F500 KNI tensile testing machine according to ASTM A3702012a standard.

\subsection{Test result}

The yield strength of pipeline steel after heat treatment is shown in Fig. 2. After heat treatment at $300^{\circ} \mathrm{C}-700^{\circ} \mathrm{C}$, the yield strength of pipeline steel increases slightly, which is mainly related to the precipitation strengthening of steel after heat treatment. In the temperature range of $700^{\circ} \mathrm{C}-900^{\circ} \mathrm{C}$, the material enters the temperature range of ferrite and austenite, and the original TMCP controlled rolling structure changes to form partial recrystallized structure. The yield strength decreases with the increase of heat treatment temperature. When the heat treatment temperature was higher than $900^{\circ} \mathrm{C}$, the buckling strength of the material increased with the increase of heat treatment temperature. The grain grew up and the yield strength began to increase after all the austenitized microstructure was cooled by air, making the two-phase region at $900{ }^{\circ} \mathrm{C}$ the lowest point of yield strength. The yield strength of sample 1 decreased by $94 \mathrm{MPa}$, that of 
sample 2 decreased by $161 \mathrm{MPa}$, that of sample 3 decreased by $212 \mathrm{MPa}$, and that of sample 4 decreased by $191 \mathrm{MPa}$. The higher the raw material strength was, the greater the yield strength decreased. When the heat treatment temperature rises to $1050^{\circ} \mathrm{C}$, the yield strength of No.2, No.3 and No.4 materials increases rapidly due to the further growth of grains.

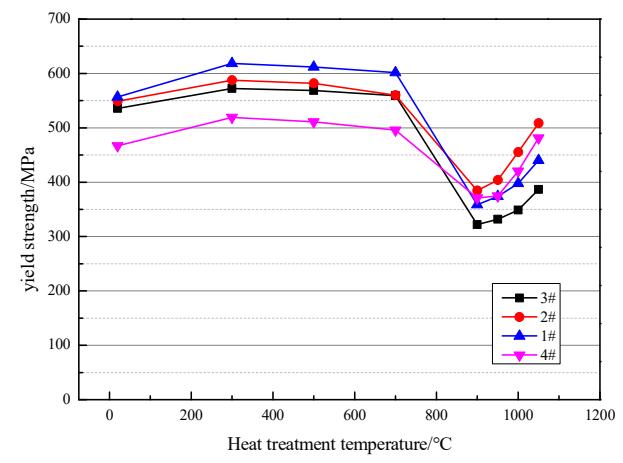

Figure 2. Yield strength of pipeline steel after heat treatment

The tensile strength of the pipeline steel after heat treatment is shown in figure 2 . When the heating temperature is not higher than $500^{\circ} \mathrm{C}$, the change of the tensile strength of the material is not obvious. With the further improvement of the heating temperature, the tensile strength of the pipeline steel decreases first and then increases, and reaches the lowest value in the temperature range of $900^{\circ} \mathrm{C} \sim 950^{\circ} \mathrm{C}$. The tensile strength of sample 1 is reduced by $194 \mathrm{MPa}$ compared with the measured value of raw materials, sample 2 is reduced by $148 \mathrm{MPa}$, sample 3 is reduced by $155 \mathrm{MPa}$, and sample 4 is reduced by $191 \mathrm{MPa}$.

By comparing the mechanical tensile properties, it is suggested that when the heat treatment temperature is higher than $700^{\circ} \mathrm{C}$, the service safety of the pipeline after heat treatment should be evaluated.

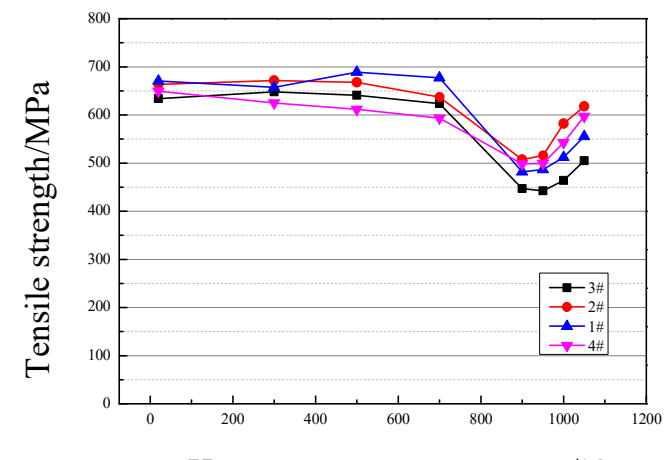

Heat treatment temperature $/{ }^{\circ} \mathrm{C}$

Fig 3 Tensile strength of pipeline steel after heat treatment

\section{Conclusion}

(1) The high temperature tensile test was used to simulate the bearing capacity of the pipeline under high temperature heating environment. It was found that the strength of the pipe maintained at the original level when the heating temperature was below $400^{\circ} \mathrm{C}$. With the increase of heating temperature, when the test temperature was higher than $400^{\circ} \mathrm{C}$, the yield strength and tensile strength of the pipe decreased significantly. When the test temperature was $450^{\circ} \mathrm{C}$, the yield strength and tensile strength of the material decreased by $15.8 \%$ and $11.1 \%$ compared with those at room temperature, respectively, which were lower than the requirements of the pipe standard. It is suggested that the pipeline pressure should be reduced when the heat treatment temperature is higher than $400^{\circ} \mathrm{C}$.

(2) The box furnace heat treatment method was used to heat the pipe, and the tensile properties of the pipe after heat treatment were tested. It was found that when the heating temperature was higher than $700^{\circ} \mathrm{C}$, the tensile properties of high grade pipeline steel pipe decreased sharply. It is suggested that when the heat treatment temperature is higher than $700^{\circ} \mathrm{C}$, the service safety of the pipeline after heat treatment should be evaluated.

\section{References}

1. WU Linjun. Reliability Analysis of Repair Technology of Pressure Pipeline in Service [J]. Quality and Technical Supervision Research, 2020(06):33-36.

2. HAO Jianbin, WU Xinjuan et al. In-Service Pipeline Repair and Simulation Testing Method of Emergency repair and Welding Process of Pipeline. OGST, 2006(02):37-40+62+2.

3. HAN Dehui. Burn Through Wall Thickness Phenomenon Analysis During Welding on Service Pipeline [J]. Welded Pipe and Tube, 2006(01):30$31+78$.

4. LU Yu-xiu, LI Qiang, CAO Yong-feng. Study on Changing Law of In-Service Welding Pool Size of Oil and Gas Pipelines [J]. Pipeline Technique and Equipment,2021(03):59-62.

5. CHEN Juan, JI Feng, LIU Xuebin, et al. Control measures of in-service pipeline welding hydrogeninduced crack under low temperature environment $[\mathrm{J}]$. Oil \& Gas Storage and Transportation, 2014,33(12):1297-1300.

6. FU Wei, LYU Yuling. Burn-though and Hydrogen Induced Cracking Prediction of Oil and Gas Pipeline during In-service Welding [J]. Hot Working Technology,2018,47(23):241-245.

7. XU Yan, LIU Ying-lai, FENG Zhen-jun, et al.. Effect of Heat Treatment Temperature on Mechanical Tensile Properties of X80 Pipeline Steel [J]. Heat Treatment Technology and Equipment ,2020,41(06):37-41. 
8. Liu Yinglai, Wang Gaofeng, Nie Xianghui, et al..Influence of Normalizing Temperature on Microstructure and Mechanical Properties of Controlled Rolling Steel for Preparation of Manifolds [J]. Natural Gas and Oil, 2015,33(05):79-83+12.

9. XU Minxu, LUO Lihui, ZHOU Huiping, et al. Influence of B -type Sleeve Welding on the Performance of X80 Pipeline Steel [J]. Materials Protection, 2019,52(06):149-156.

10. XU Yan, LIU Ying-lai, NIE Xiang-hui, et al. Influence of Process Parameters on the Forming Quality of L360M Steel Grade with Small Bending Radius Bend [J]. Heat Treatment Technology and Equipment, 2020,41(04):16-20. 